\title{
Stable isotope study of a new chondrichthyan fauna (Kimmeridgian, Porrentruy, Swiss Jura): an unusual freshwater-influenced isotopic composition for the hybodont shark Asteracanthus
}

\author{
L. Leuzinger ${ }^{1,2, a}$, L. Kocsis ${ }^{3,4}$, J.-P. Billon-Bruyat ${ }^{2}$, S. Spezzaferri ${ }^{1}$, and T. Vennemann ${ }^{3}$ \\ ${ }^{1}$ Département des Géosciences, Université de Fribourg, Chemin du Musée 6, 1700 Fribourg, Switzerland \\ ${ }^{2}$ Section d'archéologie et paléontologie, Office de la culture, République et Canton du Jura, Hôtel des Halles, 2900 \\ Porrentruy, Switzerland \\ ${ }^{3}$ Institut des Dynamiques de la Surface Terrestre, Université de Lausanne, Quartier UNIL-Mouline, Bâtiment Géopolis, 1015 \\ Lausanne, Switzerland \\ ${ }^{4}$ Universiti Brunei Darussalam, Faculty of Science, Geology Group, Jalan Tungku Link, BE 1410, Brunei Darussalam \\ anow at: CRILAR, 5301 Anillaco, La Rioja, Argentina
}

Correspondence to: L. Leuzinger (leuzinger.lea@gmail.com)

Received: 12 June 2015 - Published in Biogeosciences Discuss.: 12 August 2015

Revised: 30 October 2015 - Accepted: 25 November 2015 - Published: 7 December 2015

\begin{abstract}
Chondrichthyan teeth (sharks, rays, and chimaeras) are mineralized in isotopic equilibrium with the surrounding water, and parameters such as water temperature and salinity can be inferred from the oxygen isotopic composition $\left(\delta^{18} \mathrm{O}_{\mathrm{p}}\right)$ of their bioapatite. We analysed a new chondrichthyan assemblage, as well as teeth from bony fish (Pycnodontiformes). All specimens are from Kimmeridgian coastal marine deposits of the Swiss Jura (vicinity of Porrentruy, Ajoie district, NW Switzerland). While the overall faunal composition and the isotopic composition of bony fish are generally consistent with marine conditions, unusually low $\delta^{18} \mathrm{O}_{\mathrm{p}}$ values were measured for the hybodont shark Asteracanthus. These values are also lower compared to previously published data from older European Jurassic localities. Additional analyses on material from Solothurn (Kimmeridgian, NW Switzerland) also have comparable, low- ${ }^{18} \mathrm{O}$ isotopic compositions for Asteracanthus. The data are hence interpreted to represent a so far unique, freshwater-influenced isotopic composition for this shark that is classically considered a marine genus. While reproduction in freshwater or brackish realms is established for other hybodonts, a similar behaviour for Asteracanthus is proposed here. Regular excursions into lower salinity waters can be linked to the age of the deposits and correspond to an ecological adaptation, most likely driven by the Kimmeridgian transgression and by the
\end{abstract}

competition of the hybodont shark Asteracanthus with the rapidly diversifying neoselachians (modern sharks).

\section{Introduction}

Chondrichthyan remains are common in the Mesozoic fossil record of Western Europe, and in many different palaeoenvironmental settings (e.g. lagoonal, open marine, reduced salinity) (Duffin and Thies, 1997; Müller, 2011; Underwood, 2002). Their teeth are predominantly composed of fluorapatite, the most resistant variety of apatite (Vennemann et al., 2001) and are continuously shed and replaced, except in chimaeras (Cappetta, 2012; Stahl, 1999). In addition to their abundance, their mechanical and chemical resistance make them an ideal material for stable isotope analyses. They mineralize in isotopic equilibrium with the surrounding water, hence their primary oxygen isotopic composition $\left(\delta^{18} \mathrm{O}_{\mathrm{p}}\right)$ reflects that of the ambient water at a given temperature when they formed (Kolodny et al., 1983; Longinelli and Nuti, 1973). This makes them a valuable palaeoenvironmental proxy, used in numerous studies (e.g. Kocsis et al., 2007; Lécuyer et al., 2003; Vennemann et al., 2001).

This research is based on fossil material - mainly chondrichthyans - found between 2000 and 2011 during 


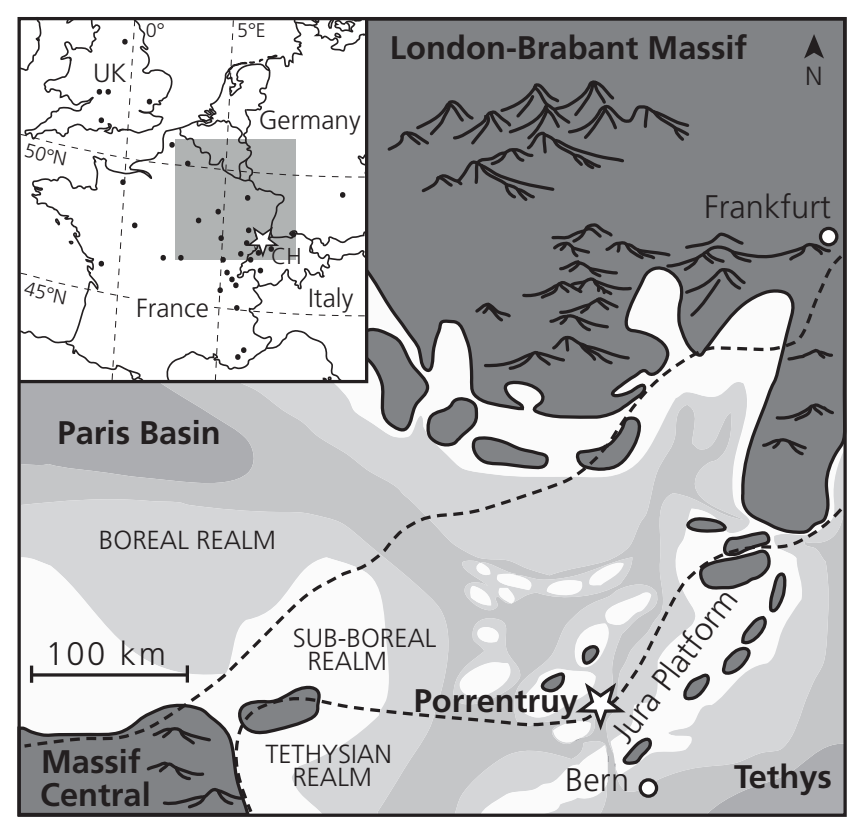

Figure 1. Palaeogeographical map of the study site and surroundings (Late Kimmeridgian, modified from Comment et al., 2011). $\mathrm{CH}=$ Switzerland, palaeolatitude of Porrentruy $=\sim 30^{\circ} \mathrm{N}$. Emerged land is outlined, darker grey corresponds to deeper water. Upper left corner: present-day geographical position of Porrentruy $(\star)$ and other European sites $(\bullet)$ of previously published studies and providing geochemical data compared in Fig. 5. The shaded square delimits the area detailed in the palaeogeographical map.

controlled palaeontological excavations conducted by the Paléontologie A16 team (PAL A16, canton of Jura, NW Switzerland). All fossiliferous sites are located in the vicinity of Porrentruy (Ajoie district) and are related to the building of the Trans-Jura highway (A16). The Ajoie region is part of the Tabular Jura (Marty et al., 2007), mainly consisting of subhorizontal Mesozoic (Oxfordian and Kimmeridgian) strata.

During the Kimmeridgian, the Ajoie region was a shallowmarine carbonate platform at a palaeolatitude of about $30^{\circ} \mathrm{N}$ (Marty, 2008) and surrounded by the Central and London Brabant massifs, the Tethys, and the Paris Basin (Fig. 1). The palaeoclimate was semi-arid with high seasonality (Philippe et al., 2010; Waite et al., 2013). The platform had a very complex morphology due to the basement structure and sealevel changes occurred during its depositional history. These processes induced several episodes of emersion suggested by numerous dinosaur footprints (Marty, 2008; Marty et al., 2007) and hardgrounds, followed by erosion and reworking. Lateral changes in water depth potentially occurred at a very local scale (Jank et al., 2006; Waite et al., 2013). The record of ammonites typical of the boreal and Tethyan domains show that the study area was influenced by water masses from both the Tethys and Paris Basin (Colombie and Rameil, 2007; Comment et al., 2011).
Based on phosphate oxygen isotope analyses obtained from this Late Jurassic chondrichthyan fauna, this study proposes answers to the following questions: (1) is there any unexpected isotopic composition for the associated marine fauna recorded in Porrentruy? (2) Are the Porrentruy isotopic data unique so far, or comparable to other European localities? (3) What do we learn about the palaeoecology of the hybodont shark Asteracanthus based on the isotopic composition?

\section{Material and methods}

The chondrichthyan dental material of the PAL A16 collection is rich and diverse, comprising more than 2000 fossils. Sharks and rays (subclass Elasmobranchii) are represented by the hybodont sharks - the extinct sister group of modern sharks (Maisey et al., 2004) (order Hybodontiformes: "Hybodus", Planohybodus, Asteracanthus) - the modern sharks (subcohort Neoselachii, order Carcharhiniformes: Palaeoscyllium, Corysodon; order Heterodontiformes: Heterodontus, Paracestracion; order Protospinaciformes: Protospinax; order Squatiniformes: Pseudorhina) and rays (superorder Batomorphii, order Rajiformes: Belemnobatis, Spathobatis). Chimaeras (superorder Holocephali (sensu Stahl, 1999), order Chimaeriformes: Ischyodus) are also present. The investigated material comes from the Kimmeridgian Reuchenette Formation and more precisely from the latest Early Kimmeridgian (Cymodoce ammonite zone, Banné Marls) and up to the Late Kimmeridgian (Mutabilis ammonite zone, Corbis Limestones and Eudoxus ammonite zone, lower Virgula Marls) (Fig. 2). Except for Asteracanthus and Ischyodus remains that are of a considerable size and were collected directly on the field, the material consists predominantly of microfossils resulting from sediment sieving.

The oxygen isotopic composition of phosphate from biogenic apatite was measured on rays, the chimaeroid Ischyodus and the hybodonts Asteracanthus and Hybodus. Bioapatite of bony fish Pycnodontiformes was also analysed for comparison. Stratigraphically, samples were selected from different beds in order to cover all units of the studied section (Fig. 2). Additionally, Kimmeridgian material from the neighbouring Natural History Museum of Solothurn was analysed for comparison.

The best mineralized part of the teeth, the enameloid, was isolated in Pycnodontiformes and Asteracanthus (Fig. 3). From eleven of the Asteracanthus teeth, dentine was also analysed in parallel to examine any isotopic differences between the tissues. In the case of chimaeroid dental plates the densest parts were selected. For the very small material (1$5 \mathrm{~mm}$ ) - as in rays and Hybodus - several isolated teeth were analysed together as bulk samples of enameloid and dentine. Due to the small size, only the outer aspect of this material was sampled as it was visibly the best preserved, i.e. not 


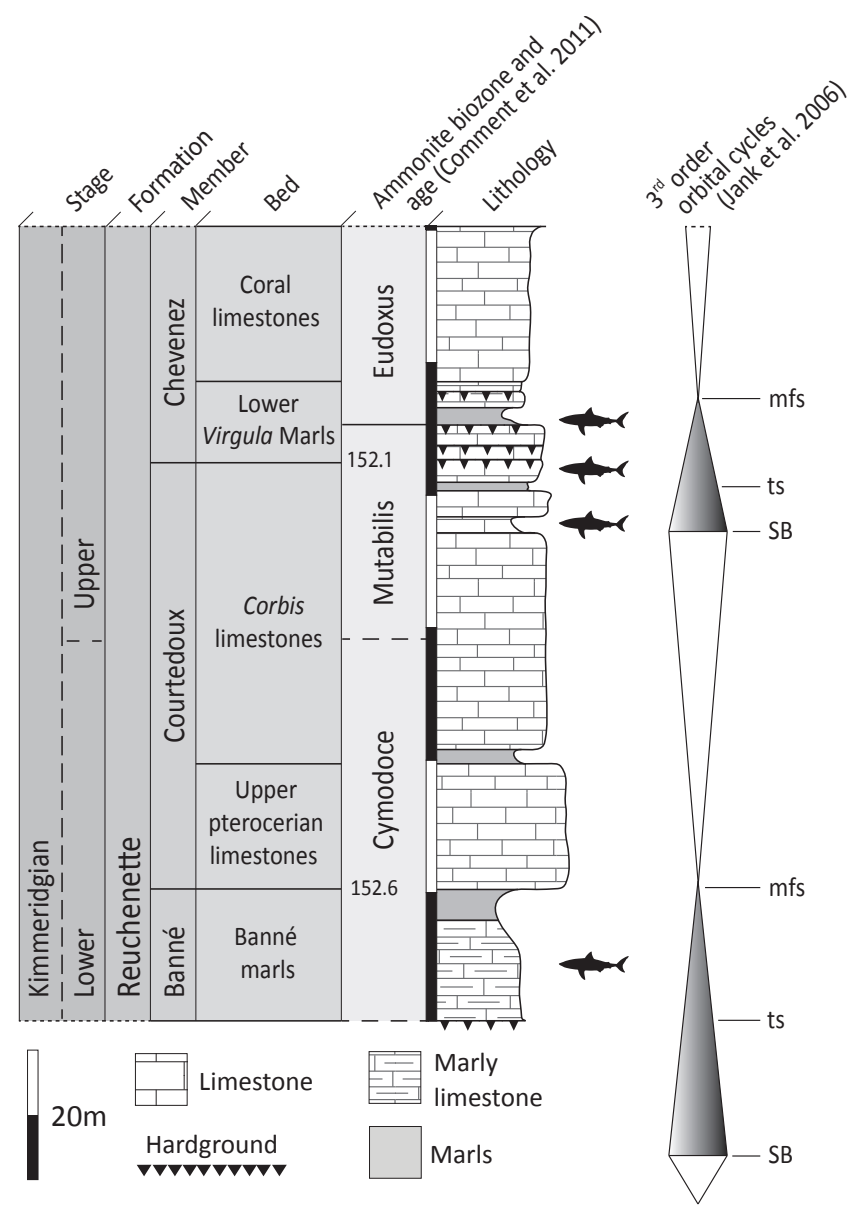

Figure 2. Simplified stratigraphic profile of the Porrentruy area with third order orbital cycles and section yielding the studied chondrichthyan material. Numbers indicate geological age in millions of years. $\mathrm{SB}=$ sequence boundary, ts = transgressive surface, $\mathrm{mfs}$ $=$ maximum flooding surface.

worn-out teeth and/or with ornamentation well defined and light-grey in colour. After manual removal of the largest part possible of the root, the most dentine-free teeth were used for analysis.

From the Porrentruy material, 38 samples of Asteracanthus teeth (27 enameloid and 11 dentine), 7 of Ischyodus dental plates and 13 of Pycnodontiformes teeth were analysed; in addition, 4 bulk samples for Hybodus and 3 for rays were investigated. From the Solothurn material, enameloid of 9 Asteracanthus and 3 Pycnodontiformes teeth were added for comparison. Altogether, a total of 77 analyses were made.

The sample powders (at least $2 \mathrm{mg}$ per sample) were pretreated following the procedure of Koch et al. (1997), and the $\mathrm{PO}_{4}^{3-}$ ion of the apatite was separated and precipitated as silverphosphate (e.g. Kocsis, 2011; O’Neil et al., 1994). NBS-120c phosphorite reference material was processed in parallel with the samples. Generally, triplicates of each sample were analysed together with two in-house phosphate stan-

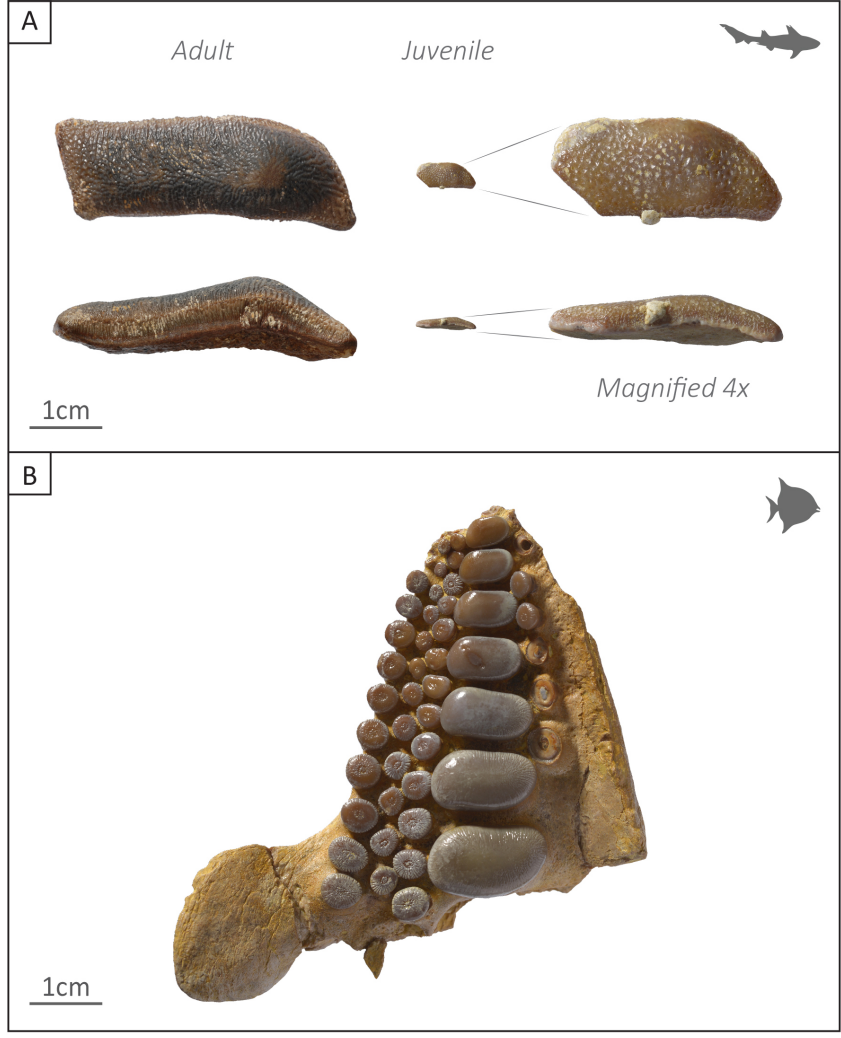

Figure 3. Fossil material from the study site of Porrentruy. (a): teeth of Asteracanthus. Left: adult specimen (SCR010-1125). Right: juvenile specimen (SCR004-221) to scale and magnified. Occlusal (top) and lateral (bottom) views. (b): left prearticular bone of Pycnodontiformes with teeth (specimen SCR010-1204). Photographs by PAL A16.

dards (LK-2L: $12.1 \%$ and LK-3L: $17.9 \%$ ) to correct the results. The samples were analysed in a high-temperature conversion elemental analyser (TC/EA) coupled to a Finningan MAT Delta Plus XL mass spectrometer at the University of Lausanne after the method described in Vennemann et al. (2002). The data are expressed in permil and reported as $\delta^{18} \mathrm{O}_{\mathrm{p}}$ on the VSMOW scale (Vienna Standard Mean Ocean Water). The overall analytical error is taken as $0.3 \%$, however individual samples often reproduced better. For the NBS-120c an average value of $21.3 \pm 0.3 \%$ o $(n=6)$ was obtained. This is somewhat lower than the mean reported value of $21.7 \%$ (e.g. Halas et al., 2011), but no correction was applied to the values measured as the small offset is thought to be due to heterogeneity in the sedimentary phosphorite and its different response to pretreatments compared to the enameloid of the teeth sampled.

The oxygen isotope composition of unaltered fish teeth $\left(\delta^{18} \mathrm{O}_{\mathrm{p}}\right)$ is a function of both water temperature and isotopic composition of ambient water $\left(\delta^{18} \mathrm{O}_{\mathrm{w}}\right)$ during tooth growth (Kolodny et al., 1983; Lécuyer et al., 2013; Longinelli and Nuti, 1973). Here below is the phosphate fractionation equa- 
tion of Lécuyer et al. (2013) used for calculating the temperature of sea water:

$$
T\left({ }^{\circ} \mathrm{C}\right)=117.4( \pm 9.5)-4.50( \pm 0.43) \cdot\left(\delta^{18} \mathrm{O}_{\mathrm{p}}-\delta^{18} \mathrm{O}_{\mathrm{w}}\right) .
$$

For marine fauna, the global, average seawater isotopic composition $\left(\delta^{18} \mathrm{O}_{\mathrm{w}}\right)$ can be used as an approximation that is assumed to be equal to $-1 \%$ for the ice-free Late Jurassic seawater (e.g. Shackleton and Kennett, 1975).

\section{Results}

For the Porrentruy samples, the bioapatite oxygen isotope compositions have a range between 17.0 and $21.9 \%$, with an overall average value of $18.8 \pm 0.9 \%$ o $(n=65)$. These values can be grouped into three ranges: (1) values of bulk samples (Hybodus and rays) and Ischyodus that are between 18.5 and $19.8 \%$ o (average $19.2 \pm 0.4 \%$ o $n=14$ ); (2) enameloid values of Asteracanthus, averaging $18.1 \pm 0.6 \%$ (17.0-19.7\%o, $n=27$ ) and (3) those of Pycnodontiformes with an average of $19.8 \pm 1.0 \%$ o $(18.2-21.9 \%$ o, $n=13)$. The average value of $18.9 \pm 0.8 \%$ o $(17.7-20.0 \%, n=11)$ in the Asteracanthus' dentine is significantly different from the equivalent enameloid sampled from the same teeth demonstrated by Student's $t$ test: $t(20)=2.98, p<0.01$.

For the Solothurn comparison material, an average of $18.7 \pm 0.9 \% \circ(n=9)$ and $19.4 \pm 0.7 \% \circ(n=3)$ was obtained for Asteracanthus and Pycnodontiformes teeth respectively.

All of the data are available and detailed in the Supplement.

\section{Associated fauna and palaeoecology}

The associated fauna of the Porrentruy material is characteristic of a coastal marine environment, with notably a rich marine bivalve assemblage, sea urchins and over 600 ammonites (Comment et al., 2011; Marty and Billon-Bruyat, 2009). Among vertebrates, coastal marine turtles (Plesiochelyidae) (Anquetin et al., 2014; Püntener et al., 2014, 2015) and crocodilians (Thalattosuchia) (Schaefer, 2012) are common.

During the Late Jurassic, modern sharks were expanding and diversifying, while hybodonts were declining and restricted more to environments of reduced salinity, or even freshwater, where modern sharks were less represented (Kriwet and Klug, 2008; Rees and Underwood, 2008; Underwood, 2002). In our assemblage however, hybodonts and rays clearly dominate ( $86 \%$ of the dental material). This suggests that conditions are still favourable to hybodonts in Porrentruy, unlike in neighbouring localities from southern Germany (Nusplingen, Solnhofen) or France (Cerin), where hybodonts are scarce or absent. Our chondrichthyan assemblage (see Sect. 2) is rather similar to that in northern Germany (e.g. in Oker) (Duffin and Thies, 1997; Thies, 1995), also dominated by hybodonts and rays. There, the fauna is associated with conditions of reduced salinity (Underwood and
Rees, 2002; Underwood and Ward, 2004; Underwood, 2002, 2004). The chimaeroid Ischyodus must also be regarded as one of the most abundant chondrichthyans, even if representing only $3 \%$ of the remains. Indeed, its nonrenewable and less resistant dentition and the relatively low amount of dental elements per individual (six dental plates against hundreds to thousands of teeth for sharks and rays) (Stahl, 1999) easily lead to an underestimate of its abundance. Interestingly, most of the few modern sharks (Neoselachii) of our assemblage (i.e. Heterodontus, Palaeoscyllium, Protospinax, Pseudorhina) are thought to have had a benthic lifestyle (Underwood, 2002; Underwood and Ward, 2004), supporting a welloxygenated bottom water, which is also indicated by the invertebrate fauna.

\section{Discussion}

\section{$5.1 \delta^{18} \mathrm{O}_{\mathrm{p}}$ values from the Porrentruy material: palaeoecological indications}

Values of bulk samples (Hybodus and rays) and Ischyodus have a similar range and could reflect either a similar habitat for these groups, or a similar diagenetic alteration. Since they correspond to dentine-bearing samples - i.e. tissues that are more easily altered than enameloid - and given that the dentine samples of Asteracanthus tend to similar values, the least resistant tissue of all these specimens could have been affected by alteration during diagenesis. Diagenetically altered isotopic values for dentine or bone are expected in fossil samples (see Lécuyer et al., 2003; Sharp et al., 2000; Pucéat et al., 2003). Therefore, in order to discuss ancient ecological parameters, we focus on enameloid samples in the rest of the text.

The isotopic compositions of Pycnodontiformes and Asteracanthus enameloid samples are considered not to have been altered, partly because of their original histological structure when examined with a microscope, their blackblueish colour when subjected to cathodoluminescence, and the generally good preservation potential for enameloid when not recrystallized (e.g. Kohn and Cerling, 2002). The distinct range in values between Asteracanthus and Pycnodontiformes enameloid, both when compared to one another and to dentine-bearing samples within the same group, further supports preservation of original values. Also, the fact that an Asteracanthus enameloid value measured on a tooth is lower than its dentine counterpart from the same tooth shows that the enameloid did not experience intense alteration, unlike the dentine that clearly recrystallized. Entirely altered specimens would give a similar value, whatever the tissue analysed. The same can be inferred from the isotopic difference between Asteracanthus and Pycnodontiformes enameloid values, which would be expected to result in similar values if they would have experienced the same diagenetic alteration (see Fischer et al., 2012). Because of these rea- 


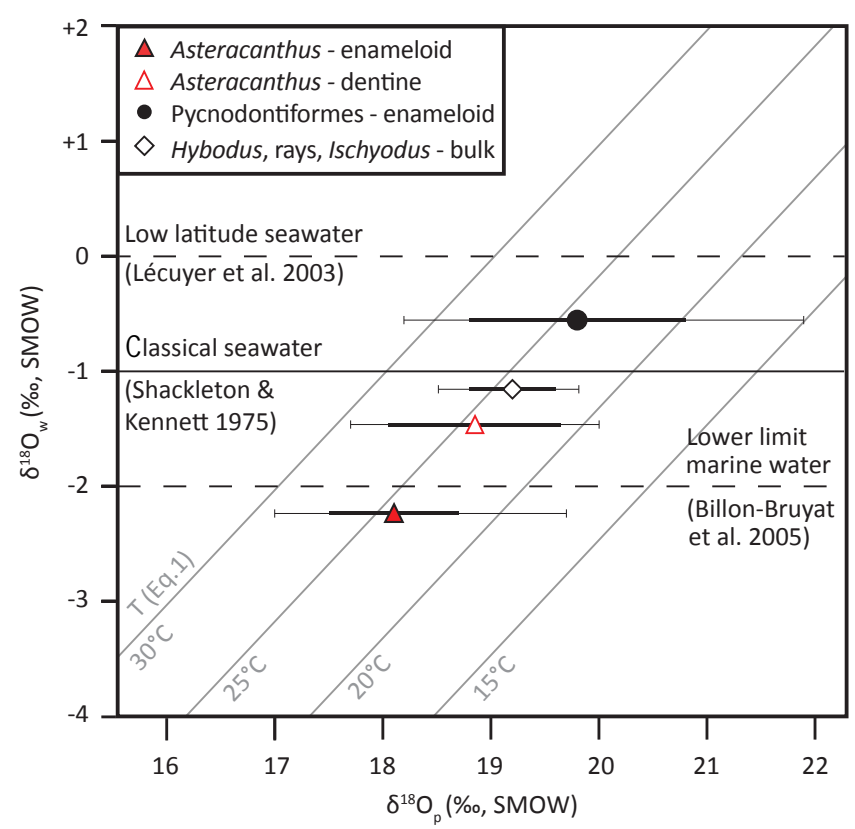

Figure 4. Graphic representation of the $\delta^{18} \mathrm{O}_{\mathrm{p}}$ values (average, standard deviation, end members) measured for Porrentruy in this study and their corresponding water temperature using Eq. (1). Comparable water temperatures for all taxa require different $\delta^{18} \mathrm{O}_{\mathrm{w}}$ values, which relate to salinity. Bulk and dentine values might have suffered diagenesis. Note the strong difference between $\delta^{18} \mathrm{O}_{\mathrm{w}}$ of Pycnodontiformes and Asteracanthus enameloid values (i.e. distinct palaeoenvironments) when similar ecological $\mathrm{T}$ is assumed. The wide value range of Pycnodontiformes indicates a tolerance to salinity fluctuations occurring within the platform, and possibly a living area broader than the shallow-marine platform. No attempt to define the final $\delta^{18} \mathrm{O}_{\mathrm{w}}$ values or water temperatures is made here.

sons, the significant differences in $\delta^{18} \mathrm{O}_{\mathrm{p}}$ values of Asteracanthus and Pycnodontiformes enameloid from Porrentruy (Student's $t$ test, $t_{(38)}=6.36, p<0.01$ ) are interpreted as reflecting actual differences in the living conditions rather than in the alteration process (Fig. 4).

Water temperatures calculated with Eq. (1) from enameloid $\delta^{18} \mathrm{O}_{\mathrm{p}}$ of Pycnodontiformes and Asteracanthus differ by $7.4{ }^{\circ} \mathrm{C}(1.6 \%)$. The two taxa are found in the same deposits and such a temperature difference is not plausible neither laterally, nor vertically, given that the water depth did not exceed a few tens of metres in the study area (Waite et al., 2013). Most of our Pycnodontiformes $\delta^{18} \mathrm{O}_{\mathrm{p}}$ values (18.2 to $21.9 \%$ ) indicate marine conditions, since they are comparable with the isotopic composition measured on several marine vertebrate taxa from the Late Jurassic of western Europe (18.5 to 22.8\%o) (see Billon-Bruyat et al., 2005; Dromart et al., 2003; Lécuyer et al., 2003). Those values are consistent with the marine conditions indicated by the associated fauna of Porrentruy. When used in Eq. (1), the Pycnodontiformes $\delta^{18} \mathrm{O}_{\mathrm{p}}$ values give a mean temperature range that is also consistent with the palaeogeographical settings of the study site $\left(23.9 \pm 4.4^{\circ} \mathrm{C}, n=13\right)$. However, the range in values is quite wide (see Fig. 4) and can be interpreted as a tolerance to salinity fluctuations for this taxon, since some of those bony fish are known to be euryhaline and are probably poor environmental indicators (Kocsis et al., 2009; Poyato-Ariza, 2005). Semi-confined lagoons induced by local depth differences on the platform and subjected to higher evaporation rates during the dry season would have been characterized by a higher salinity and thus higher isotopic composition, potentially recorded by Pycnodontiformes. For the lowest value $(18.2 \%$ ) , an influence of a slightly reduced salinity cannot be excluded. On the other hand, the highest values can also be interpreted as reflecting a deeper, cooler environment around the platform. The good state of preservation of Pycnodontiformes remains and the presence of several mandibles and tooth palates suggest that the material was not transported over long distances.

The preservation of the fine ornamentation of Asteracanthus teeth also suggests that they lived in the vicinity, even if the isotopic composition of Asteracanthus is significantly different from that of Pycnodontiformes. Also, the associated record of several large Asteracanthus fin spines in marly deposits of the Lower Virgula Marls (lagoonal deposits indicating a low-energy context) (see Waite et al., 2013) argues against long distances of sediment transport for those relatively large fossils (up to $26.5 \mathrm{~cm}$ long), supporting an autochthonous character of this genus. Moreover, the preservation of the root in several Asteracanthus teeth - an indication of post-mortem embedding rather than tooth loss in hybodonts (Underwood and Cumbaa, 2010) - also precludes transport. Yet, temperatures obtained with Asteracanthus enameloid samples using the Eq. (1) are higher (average $\left.31.3 \pm 2.9^{\circ} \mathrm{C}, n=27\right)$. This could imply a habitat closer to the sea surface but would then also suggest a possible influence of more evaporative conditions on the oxygen isotope composition of the water with $\delta^{18} \mathrm{O}_{\mathrm{w}}$ values higher than the global average used above (i.e. $1 \% o$ ). For example, $0 \%$ as proposed by Lécuyer et al. (2003) for low-latitude marginal seas with high evaporation rates. However, higher $\delta^{18} \mathrm{O}$ values of water would also result in higher temperatures calculated with an average of $35.8^{\circ} \mathrm{C}$ and a maximum reaching $41.0^{\circ} \mathrm{C}$, which are considered unrealistic. A more consistent explanation is to consider Asteracanthus as living in a freshwater-influenced environment, i.e. an environment with a lower $\delta^{18} \mathrm{O}_{\mathrm{w}}$ value (Fig. 4).

\subsection{Shark nurseries in reduced salinity environments for Asteracanthus?}

Assessing the tooth replacement rate of an extinct shark is difficult, and studies of such rates are scarce (e.g. Botella et al., 2009). However, Asteracanthus possesses a crushing dentition composed of a rather small amount of large teeth (see figure in Rees and Underwood, 2008, p. 136) organized in a relatively low number of files and rows (sensu 
Cappetta, 2012); hence, a relatively slow replacement rate is likely, compared to other sharks with numerous slender, cuspidated teeth adapted to clutch and tear their prey. This implies that the $\delta^{18} \mathrm{O}_{\mathrm{p}}$ values of Asteracanthus potentially reflect an average of the surrounding water parameters over a relatively longer growing period. The lower $\delta^{18} \mathrm{O}_{\mathrm{p}}$ values of Asteracanthus, compared to typical Late Jurassic marine compositions (see data from marine vertebrates of other studies in Sect. 5.1), corresponds either to a constant brackish living environment or to a marine environment with regular excursions into fresh- or brackish waters (or vice-versa). As Asteracanthus remains were not re-sedimented nor transported over long distances, it can be proposed that they partly inhabited the marine realm, as indicated by the associated fauna, but not continuously. Lateral salinity changes are readily caused by rainy winters coupled with an irregular morphology of the platform, creating marked depth differences and lagoons (Waite et al., 2013) where the proportion of meteoric water could have been important. However, excursions into more distant brackish and/or freshwater realms can also be considered. Extant elasmobranchs that occupy different environmental niches during relatively long period of their lives (not necessarily with salinity variations) can do so for different reasons: seasonal environmental changes, reproduction, and development in a distinct environment during the first ontogenetic stages (White and Sommerville, 2010).

More than 130 Asteracanthus teeth were found in the Porrentruy excavation sites. Only four of them appeared to be clearly undersized $(<1 \mathrm{~cm})$ (Fig. 3). As illustrated in Rees and Underwood (2008, p. 136), the size difference between lingual-most and labial-most teeth of any file is quite small in Asteracanthus medius. Even if a stronger heterodonty cannot be excluded for other species of the genus, it seems more likely that the clearly undersized dental material belonged to juvenile individuals. The record of hundreds of submillimetric fish remains such as dermal denticles resulting from sieving of hundreds of kilograms of sediments exclude a taphonomic bias linked to the size of the teeth. Asteracanthus juveniles could have spent the first period of their life in estuaries, rivers or lagoons, sheltered from predators such as crocodilians or the bony fish Caturus. Extant euryhaline bull shark females (Carcharhinus leucas) and their juveniles are known to have a similar behaviour (Jenson, 1976; Pillans et al., 2005), as is the case for some small hybodont sharks (Fischer et al., 2011; Klug et al., 2010). The location of this environment with reduced salinity remains open, especially since some sharks are known to migrate across very long distances, e.g. the blacktip shark (Castro, 1996). Regarding the fish faunal composition of Porrentruy, salinity fluctuations within the study area cannot be excluded. Two of the most abundant bony fish taxa recorded - Pycnodontiformes and "Lepidotes" - are known to tolerate salinity fluctuations (Amiot et al. 2010; Kocsis et al., 2009; Poyato-Ariza, 2005). Additionally, several chondrichthyan taxa recorded are potential indicators of reduced salinity: the chimaeroid genus Ischy- odus was reported in Jurassic freshwater deposits of Russia (Popov and Shapovalov, 2007) and can therefore not be considered as strictly marine. The modern shark Palaeoscyllium, relatively scarce but present in our fossil assemblage, is the oldest modern shark known to tolerate freshwater, so far only in the Cretaceous though (Sweetman and Underwood, 2006). Finally, and as mentioned above, hybodonts and rays are in some cases also linked to reduced salinity conditions (Duffin and Thies, 1997; Thies, 1995). Salinity fluctuations (from pliohaline to brachyhaline) are supported by different ostracods assemblages in the study site (Schudack et al., 2013), yet they overwhelmingly indicate brachyhaline conditions in our sample sections.

In Fig. 5, the oxygen isotopic compositions of Pycnodontiformes and Asteracanthus enameloid samples measured in this study are shown for the Porrentruy and Solothurn localities and compared to previously published data from others - mostly older - Swiss, French, and British Jurassic localities (Billon-Bruyat et al., 2005; Dromart et al., 2003; Lécuyer et al., 2003). Generally, the Porrentruy Asteracanthus $\delta^{18} \mathrm{O}_{\mathrm{p}}$ values - especially in the Late Kimmeridgian - are lower than in other studies, while Pycnodontiformes values are comparable. The material from Solothurn (Kimmeridgian) a locality with similar palaeoenvironment but under Tethyan influence only - shows some affinities with the Porrentruy material, for instance with unusually low oxygen isotope values for several Asteracanthus. The Porrentruy Asteracanthus $\delta^{18} \mathrm{O}_{\mathrm{p}}$ values tend to get lower in the Upper Kimmeridgian but this trend must be considered with caution due to the relatively small amount of Lower Kimmeridgian samples.

This global comparison suggests that the low $\delta^{18} \mathrm{O}_{\mathrm{p}}$ values measured for Asteracanthus here are likely linked to the age of the deposits. Interestingly, a tolerance of Asteracanthus to salinity variations has briefly been mentioned by Kriwet (2000), based on its presence in the younger deposits of the Purbeck and Wealden group in southern England (Woodward, 1895). Asteracanthus remains from freshwater deposits are also recorded in the Upper Cretaceous of Sudan (Buffetaut et al., 1990). The present data indicate an adaptation to a wider salinity range through time and in the Kimmeridgian already, maybe in response to the spectacular diversification of modern sharks in the marine realms of Western Europe at the end of the Jurassic (Cuny and Benton, 1999). Also, the shallow-water platform of NW Switzerland may have somehow represented a shelter for the hybodonts, still dominating the shark fauna around Porrentruy. The high sea-level in the Kimmeridgian (Hardenbol et al., 1998) could have opened new niches in shallow-water environments that was influenced by freshwater run-offs. These new living places could have provided shelter and nursery ground for Asteracanthus.

This is the first isotopic evidence of a euryhaline ecology for the large, durophagous shark Asteracanthus, classically considered as marine (Agassiz, 1843; Rees and Underwood, 2006, 2008). 


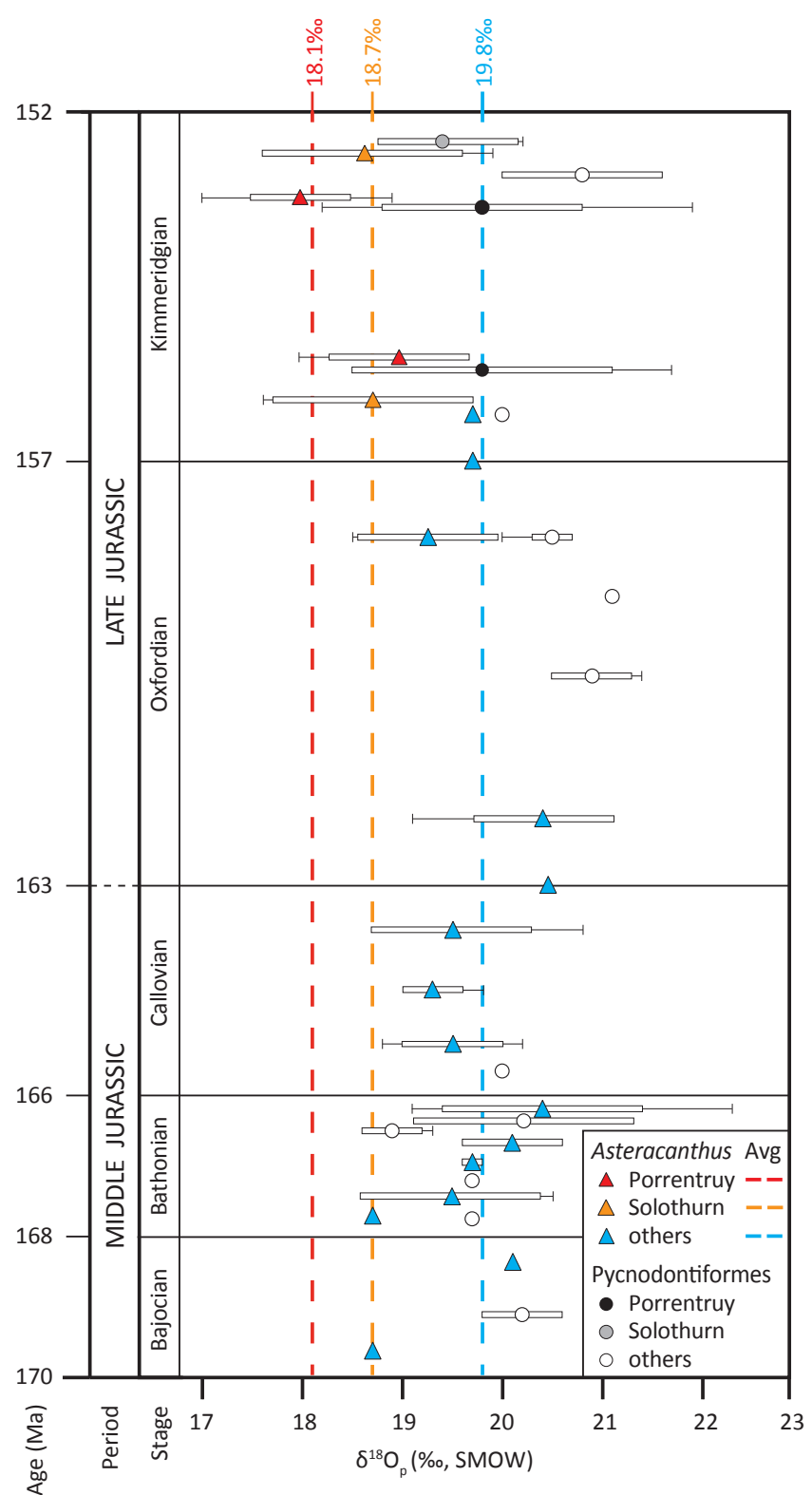

Figure 5. Comparison of $\delta^{18} \mathrm{O}_{\mathrm{p}}$ values (average, standard deviation, end members) of Pycnodontiformes and Asteracanthus enameloid samples from Porrentruy, Solothurn and other European localities through time. The stratigraphical position is approximate and corresponds to Early, Middle, Late divisions of each stage. The approximate geographical positions of previously studied localities (Dromart et al., 2003; Lécuyer et al., 2003; Billon-Bruyat et al., 2005) are shown in Fig. 1. Detailed localities and stratigraphic positions are available in the Supplement.

\section{Concluding remarks}

1. Most of the $\delta^{18} \mathrm{O}_{\mathrm{p}}$ values of enameloid measured in the hybodont shark Asteracanthus are too low to reflect fully marine conditions.
2. Comparisons with geochemical data of older European Jurassic localities confirm the unusual character of the Asteracanthus isotopic compositions measured in the material from this study. This new freshwaterinfluenced isotopic composition of Asteracanthus is likely linked to a change in its ecology through geologic time, as suggested by similar results obtained with Kimmeridgian material from Solothurn. The Kimmeridgian transgression (i.e. opening of new shallow-water niches) (see Fig. 2) and probably competing stress from quickly diversifying neoselachians could have played an important role in the adaptation to brackish and freshwater realms.

3. A predominantly marine ecology is proposed for Asteracanthus, combined with regular excursions into freshwater and/or brackish environments, possibly for reproduction purposes considering the rarity of juvenile material in the marine, depositional environment.

\section{The Supplement related to this article is available online at doi:10.5194/bg-12-6945-2015-supplement.}

Acknowledgements. We thank the PAL A16 team for making available the fossil material, as well as precious field details, geological data and figures, and also for inspiring discussions. The photographs of the material were kindly taken by Bernard Migy and Olivier Noaillon. We really appreciate the help of S. Thüring from the Natural History Museum of Solothurn for providing additional fossil material for comparative purposes and the assistance of scientists and technicians at the University of Fribourg (B. Grobéty, A. Foubert, P. Dietsche) for preparing tooth thin-sections and making available microscopes. Thank you to G. Cuny for his help in the identification of the fossil material. We also want to thank C. Meier for details on the stratigraphy of Solothurn. Thank you to M. Hechenleitner for his help in finalizing this paper. The authors are also grateful for the constructive comments of two reviewers, J. Fischer and R. Amiot.

This study was funded by the Section d'archéologie et paléontologie (Canton Jura) and the Federal Road Office from Switzerland. L. Kocsis received support from the Swiss National Science Foundation (SNF PZ00P2_126407) while this research was conducted.

Edited by: E. J. Javaux

\section{References}

Agassiz, L. J. R.: Recherches sur les poissons fossiles, Imprimerie de Petipierre, Neuchâtel, Volume 3, 390 pp., 1843.

Amiot, R., Wang, X., Lécuyer, C., Buffetaut, E., Boudad, L., Cavin, L., Ding, Z., Fluteau, F., Kellner, A. W. A, Tong, H., and Zhang, F.: Oxygen and carbon isotope compositions of middle 
Cretaceous vertebrates from North Africa and Brazil: Ecological and environmental significance, Palaeogeogr. Palaeoclimatol. Palaeoecol., 297, 439-451, doi:10.1016/j.palaeo.2010.08.027, 2010.

Anquetin, J., Püntener, C., and Billon-Bruyat, J.-P.: A taxonomic review of the Late Jurassic eucryptodiran turtles from the Jura Mountains (Switzerland and France), Peer J., 2, e369, doi:10.7717/peerj.369, 2014.

Billon-Bruyat, J.-P., Lécuyer, C., Martineau, F., and Mazin, J.M.: Oxygen isotope compositions of Late Jurassic vertebrate remains from lithographic limestones of western Europe: implications for the ecology of fish, turtles, and crocodilians, Palaeogeogr. Palaeoclimatol. Palaeoecol., 216, 359-375, doi:10.1016/j.palaeo.2004.11.011, 2005.

Botella, H., Valenzuela-Ríos, J. I., and MartínezPerez, C.: Tooth replacement rates in early chondrichthyans: A qualitative approach, Lethaia, 42, 365-376, doi:10.1111/j.15023931.2009.00152.x, 2009.

Buffetaut, E., Bussert, R., and Brinkman, W.: A new nonmarine vertebrate fauna in the Upper Cretaceous of northern Sudan, Berliner Geowissenschaftlische Abhandlungen, A 120, 183-202, 1990.

Cappetta, H.: Chondrichthyes. Mesozoic and Cenozoic Elasmobranchii: Teeth, Dr. Friedr., edited by: Schultze, H.-P., Handbook of Paleoichthyology, Volume 3E, Munich, 2012.

Castro, J. I.: Biology of the blacktip shark,Carcharhinus limbatus, off the southeastern United States, Bull. Mar. Sci., 59, 508-522, 1996.

Colombié, C., and Rameil, N.: Tethyan-to-boreal correlation in the Kimmeridgian using high-resolution sequence stratigraphy (Vocontian Basin, Swiss Jura, Boulonnais, Dorset), Int. J. Earth Sci., 96, 567-591, doi:10.1007/s00531-006-0117-3, 2007.

Comment, G., Ayer, J., and Becker, D.: Deux nouveaux membres lithostratigraphiques de la Formation de Reuchenette (Kimméridgien, Ajoie, Jura suisse) - Nouvelles données géologiques et paléontologiques acquises dans le cadre de la construction de l'autoroute A16 (Transjurane), Swiss Bull. f. Angew. Geol., 16, 3-24, 2011.

Cuny, G. and Benton, M. J.: Early radiation of the neoselachian sharks in western Europe, Geobios, 32, 193-204, 1999.

Dromart, G., Garcia, J.-P., Gaumet, F., Picard, S., Rousseau, M., Atrops, F., Lécuyer, C., and Sheppard, S. M. F.: Perturbation of the carbon cycle at the Middle/Late Jurassic transition: geological and geochemical evidence, Am. J. Sci., 303, 667-707, 2003.

Duffin, C. J. and Thies, D.: Hybodont shark teeth from the Kimmeridgian (Late Jurassic) of northwest Germany, Geol. Palaeontol., 31, 235-256, 1997.

Fischer, J., Voigt, S., Schneider, J. W., Buchwitz, M., and Voigt, S.: A selachian freshwater fauna from the Triassic of Kyrgyzstan and its implication for Mesozoic shark nurseries, J. Vertebr. Paleontol., 31, 937-953, 2011.

Fischer, J., Voigt, S., Franz, M., Schneider, J. W., Joachimski, M. M., Tichomirowa, M., Götze, J., and Furrer, H.: Palaeoenvironments of the late Triassic Rhaetian Sea: Implications from oxygen and strontium isotopes of hybodont shark teeth, Palaeogeogr. Palaeoclimatol. Palaeoecol., 353-355, 6072, doi:10.1016/j.palaeo.2012.07.002, 2012.

Halas, S., Skrzypek, G., Meier-Augenstein, W., Pelc, A., and Kemp, H.F. Inter-laboratory calibration of new silver orthophosphate comparison materials for the stable oxygen isotope analysis of phosphates, Rapid Commun. Mass Spectrom. 25, 579-584, 2011.

Hardenbol, J., Thierry, J., Farley, M. B., Jacquin, T., de Graciansky, P.-C., and Vail, P. R.: Mesozoic and Cenozoic sequence chronostratigraphic framework of European basins: Mesozoic-Cenozoic Sequence, Stratigr. Eur. Basins SEPM Spec. Publ., 60, 3-13 and 763-781, 1998.

Jank, M., Meyer, C., and Wetzel, A.: Late Oxfordian to Late Kimmeridgian carbonate deposits of NW Switzerland (Swiss Jura): Stratigraphical and palaeogeographical implications in the transition area between the Paris Basin and the Tethys, Sediment Geol., 186, 237-263, doi:10.1016/j.sedgeo.2005.08.008, 2006.

Jenson, N. H.: Reproduction of the bull shark, Carcharhinus leucas, in the Lake Nicaragua-Rio San Juan System, Investig. Ichthyofauna Nicar. Lakes, 40, 539-559, 1976.

Klug, S., Tütken, T., Wings, O., Pfretzschner, H., and Martin, T.: A Late Jurassic freshwater shark assemblage (Chondrichthyes, Hybodontiformes) from the southern Junggar Basin, Xinjiang, Northwest China, Palaeobiodivers. Palaeoenviron., 90, 241-257, doi:10.1007/s12549-010-0032-2, 2010.

Koch, P. L., Tuross, N., and Fogel, M. L.: The Effects of Sample Treatment and Diagenesis on the Isotopic Integrity of Carbonate in Biogenic Hydroxylapatite, J. Archaeol. Sci., 24, 417-429, 1997.

Kocsis, L.: Geochemical compositions of marine fossils as proxies for reconstructing ancient environmental conditions, Chimia, 65, 787-791, 2011.

Kocsis, L., Vennemann, T. W., and Fontignie, D.: Migration of sharks into freshwater systems during the Miocene and implications for Alpine paleoelevation, Geology, 35, 451-454, doi:10.1130/G23404A.1, 2007.

Kocsis, L., Ôsi, A., Vennemann, T., Trueman, C. N., and Palmer, M. R.: Geochemical study of vertebrate fossils from the Upper Cretaceous (Santonian) Csehbánya Formation (Hungary): Evidence for a freshwater habitat of mosasaurs and pycnodont fish, Palaeogeogr. Palaeoclimatol. Palaeoecol., 280, 532-542, doi:10.1016/j.palaeo.2009.07.009, 2009.

Kohn, M. J. and Cerling, T. E.: Stable Isotope Compositions of Biological Apatite, in Phosphate: Geochemical, Geobiological, and Materials Importance, Mineralogy and Geochemistry, 48, Mineral. Soc. Am. Rev., 4, 455-488., 2002.

Kolodny, Y., Luz, B., and Navon, O.: Oxygen isotope variations in phosphate of biogenic apatites: fish bone apatite - rechecking the rules of the game, Earth Planet. Sci. Lett., 64, 398-404, 1983.

Kriwet, J.: The fish fauna from the Guimarota mine, in Guimarota A Jurassic Ecosystem, edited by: Martin T. and Krebs, B., 41-50, Munich, 2000.

Kriwet, J. and Klug, S.: Diversity and biogeography patterns of Late Jurassic neoselachians (Chondrichthyes: Elasmobranchii), Geol. Soc. London, Spec. Publ., 295, 55-70, doi:10.1144/SP295.5, 2008.

Lécuyer, C., Picard, S., Garcia, J.-P., Sheppard, S. M. F., Grandjean, P., and Dromart, G.: Thermal evolution of Tethyan surface waters during the Middle-Late Jurassic: Evidence from $\delta^{18} \mathrm{O}$ values of marine fish teeth, Paleoceanography, 18, 1-16, doi:10.1029/2002PA000863, 2003.

Lécuyer, C., Amiot, R., Touzeau, A., and Trotter, J.: Calibration of the phosphate $\delta^{18} \mathrm{O}$ thermometer with carbonate-water oxy- 
gen isotope fractionation equations, Chem. Geol., 347, 217-226, doi:10.1016/j.chemgeo.2013.03.008, 2013.

Longinelli, A. and Nuti, S.: Oxygen isotope measurements of phosphate from fish teeth and bones, Earth Planet. Sci. Lett., 20, 337340, 1973.

Maisey, J. G., Naylor, J. P., and Ward, D. J.: Mesozoic elasmobranchs, neoselachian phylogeny and the rise of modern elasmobranch diversity, in: Mesozoic Fishes 3 - Systematics, Paleoenvironments and Biodiversity, Proceeding of the international meeting Serpiano, 2001, edited by: Arratia, G., and Tintori, A., Verlag Dr. Friedrich Pfeil, München, 17-56, 2004.

Marty, D.: Sedimentology, taphonomy, and ichnology of Late Jurassic dinosaur tracks from the Jura carbonate platform (ChevenezCombe Ronde tracksite, NW Switzerland): insights into the tidalflat palaeoenvironment and dinosaur diversity, locomotion, and palaeoecology, GeoFocus, 21, 278 pp., 2008.

Marty, D. and Billon-Bruyat, J.-P.: Field-trip to the excavations in the Late Jurassic along the future Transjurane highway near Porrentruy (Canton Jura, NW Switzerland): dinosaur tracks, marine vertebrates and invertebrates, in 5th International Symposium on Lithographic Limestone and Plattenkalk, 94-129., 2009.

Marty, D., Ayer, J., Becker, D., Berger, J.-P., Billon-Bruyat, J.-P., Braillard, L., Hug, W. A., and Meyer, C.: Late Jurassic dinosaur tracksites of the Transjurane highway (Canton Jura, NW Switzerland): overview and measures for their protection and valorisation, Bull. f. Angew. Geol., 12, 75-89, 2007.

Müller, M. K.: The fish fauna of the Late Jurassic Solothurn Turtle Limestone (NW Switzerland), Swiss J. Geosci., 104, 133-146, doi:10.1007/s00015-011-0061-5, 2011.

O’Neil, J. R., Roe, L. J., Reinhard, E., and Blake, R. E.: A rapid and precise method of oxygen isotope analysis of biogenic phosphate, Isr. J. Earth Sci., 43, 203-212, 1994.

Philippe, M., Billon-Bruyat, J.-P., Garcia-Ramos, J. C., Bocat, L., Gomez, B., and Piñuela, L.: New occurrences of the wood Protocupressinoxylon purbeckensis Francis: implications for terrestrial biomes in southwestern Europe at the Jurassic/Cretaceous boundary, Palaeontology, 53, 201-214, doi:10.1111/j.14754983.2009.00926.x, 2010.

Pillans, R. D., Good, J. P., Anderson, W. G., Hazon, N., and Franklin, C. E.: Freshwater to seawater acclimation of juvenile bull sharks (Carcharhinus leucas): plasma osmolytes and $\mathrm{Na}^{+} / \mathrm{K}^{+}$-ATPase activity in gill, rectal gland, kidney and intestine, J. Comp. Physiol. B., 175, 37-44, doi:10.1007/s00360-0040460-2, 2005.

Popov, E. V. and Shapovalov, K. M.: New finds of chimaeroid fishes (Holocephali, Chimaeroidei) from the Jurassic of European Russia, in: Modern Russian paleontology: classic and newest methods, vol. C, edited by: Rozanov, A. Y., 25-44, Paleontological Institute, Russian Academy of Sciences, Moscow, 2007.

Poyato-Ariza, F. J.: Pycnodont fishes: morphologic variation, ecomorphologic plasticity, and a new interpretation of their evolutionary history, Bull. Kitakyushu Museum Nat. Hist. Hum. Hist., A, 169-184, 2005.

Pucéat, E., Lécuyer, C., Sheppard, S. M. F., Dromart, G., Reboulet, S., and Grandjean, P.: Thermal evolution of Cretaceous Tethyan marine waters inferred from oxygen isotope composition of fish tooth enamels, Paleoceanography, 18, 1-12, doi:10.1029/2002PA000823, 2003.
Püntener, C., Billon-Bruyat, J.-P., Bocat, L., Berger, J.-P., and Joyce, W. G.: Taxonomy and phylogeny of the turtle Tropidemys langii Rütimeyer, 1873, based on new specimens from the Kimmeridgian of the Swiss Jura Mountains, J. Vertebr. Paleontol., 34, 353374, doi:10.1080/02724634.2013.804412, 2014.

Püntener, C., Anquetin, J., and Billon-Bruyat, J.-P.: Thalassemys bruntrutana n. sp., a new coastal marine turtle from the Late Jurassic of Porrentruy (Switzerland), and the paleobiogeography of the Thalassemydidae, Peer J., 3, e1282, doi:10.7717/peerj.1282, 2015.

Rees, J. and Underwood, C. J.: Hybodont sharks from the Middle Jurassic of the Inner Hebrides, Scotland, Trans. R. Soc. Edinb. Earth Sci., 96, 351-363, 2006.

Rees, J. and Underwood, C. J.: Hybodont sharks of the English Bathonian and Callovian (Middle Jurassic), Palaeontology, 51, 117-147, doi:10.1111/j.1475-4983.2007.00737.x, 2008.

Schaefer, K.: Variabilité de la morphologie dentaire des crocodiliens marins (Thalattosuchia) du Kimméridgien d'Ajoie (Jura, Suisse), M.S. thesis, University of Fribourg, Switzerland, 111 pp., 2012.

Schudack, U., Schudack, M., Marty, D., and Comment, G.: Kimmeridgian (Late Jurassic) ostracods from Highway A16 (NW Switzerland): taxonomy, stratigraphy, ecology, and biogeography, Swiss J. Geosci., 106, 371-395, doi:10.1007/s00015-0130138-4, 2013.

Shackleton, N. and Kennett, J. P.: Paleotemperature history of the Cenozoic and the initiation of Antarctic glaciation: oxygen and carbon isotope analyses in DSDP sites 277, 279, and 281, Initial Reports Deep Sea Drill. Proj., 29, 743-756, 1975.

Sharp, Z. D., Atudorei, V., and Furrer, H.: The effect of diagenesis on oxygen isotope ratios of biogenic phosphates, Am. J. Sci., 3000, 222-237, 2000.

Stahl, B. J.: Chondrichthyes III. Holocephali, Dr. Friedr., edited by: Schultze, H.-P., Handbook of Paleoichthyology, Volume E, Munich, 169 pp., 1999.

Sweetman, S. C. and Underwood, C. J.: A Neoselachian shark from the non-marine Wessex Formation (Wealden Group: Early Cretaceous, Barremian) of the Isle of Wight, southern England, Palaeontology, 49, 457-465, 2006.

Thies, D.: Placoid scales (Chondrichthyes: Elasmobranchii) from the Late Jurassic (Kimmeridgian) of northern Germany, J. Vertebr. Paleontol., 15, 463-481, 1995.

Underwood, C. J.: Sharks, rays and a chimaeroid from the Kimmeridgian (Late Jurassic) of Ringstead, Palaeontology, 45, 297325, 2002.

Underwood, C. J.: Environmental controls on the distribution of neoselachian sharks and rays within the British Bathonian (Middle Jurassic), Palaeogeogr. Palaeoclimatol. Palaeoecol., 203, 107-126, doi:10.1016/S0031-0182(03)00663-1, 2004.

Underwood, C. J. and Cumbaa, S. L.: Chondrichthyans from a Cenomanian (Late Cretaceous) bonebed, Saskatchewan, Canada, Palaeontology, 53, 903-944, doi:10.1111/j.14754983.2010.00969.x, 2010.

Underwood, C. J. and Rees, J.: Selachian faunas from the Earliest Cretaceous Purbeck Groups of Dorset, Southern England, Spec. Pap. Palaeontol., 68, 107-119, 2002.

Underwood, C. J. and Ward, D. J.: Neoselachian sharks and rays from the British Bathonian (Middle Jurassic), Palaeontology, 47, 447-501, 2004. 
Vennemann, T., Hegner, E., Cliff, G., and Benz, G. W.: Isotopic composition of recent shark teeth as a proxy for environmental conditions, Geochim. Cosmochim. Acta, 65, 1583-1599, 2001.

Vennemann, T. W., Fricke, H. C., Blake, R. E., O’Neil, J. R., and Colman, A.: Oxygen isotope analyses of phosphates: a comparison of techniques for analysis of $\mathrm{Ag}_{3} \mathrm{PO}_{4}$, Chem. Geol., 185, 321-336, 2002.

Waite, R., Marty, D., Strasser, A., and Wetzel, A.: The lost paleosols: Masked evidence for emergence and soil formation on the Kimmeridgian Jura platform (NW Switzerland), Palaeogeogr. Palaeoclimatol. Palaeoecol., 376, 73-90, 2013.
White, W. T. and Sommerville, E.: Elasmobranchs of Tropical Marine Ecosystems, in Sharks and their relatives II - Biodiversity, adaptive Physiology, and Conservation, edited by: Carrier, J. C., Musick, J. A., and Heithaus, M. R., 160-200, CRC Press, London New York, 2010.

Woodward, A. S.: Catalogue of the fossil fishes in the British $\mathrm{Mu}-$ seum (Natural History), British Museum (Natural History) Dept. of Geology, 1889-1901, 1895. 